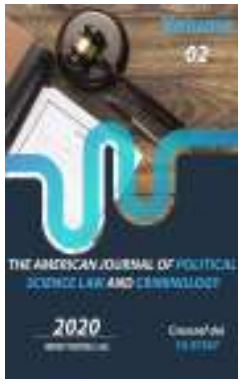

Journal Website: http://usajournalshub.c om/index,php/tajpslc

Copyright: Original content from this work may be used under the terms of the creative commons attributes 4.0 licence.

\section{Legal Support For The Protection Of The Rights Of Witnesses In The Fight Against Organized Crime}

\section{Giyosov Bahriddin Hasan Ogli}

Group Commander of The Faculty Of Vocational Training Of The Military Technical Institute of The National Guard Of The Republic Of Uzbekistan

Kholmurodov Doniyor Bakhtiyor Ogli

Commander Of The Cadet Battalion Of The Military-Technical Institute Of The National Guard Of The Republic Of Uzbekistan

\title{
ABSTRACT
}

This article provides comments and suggestions on how to protect witnesses from law enforcement in the fight against organized crime. In addition, the foreign experience in this area and the current legislation of the Republic of Uzbekistan were analyzed.

\section{KEYWORDS}

Law, rule of law, law enforcement, victim, witness, witness protection, organized crime, protection measures.

\section{INTRODUCTION}

In accordance with the Action Strategy for the Development of Uzbekistan for 2017-2021 "Priorities for further rule of law and further reform of the judicial system"[1] and in accordance with the decree of the President of the Republic of Uzbekistan PF-5308 dated january 22, 2018. The task was to develop a draft law of the Republic of Uzbekistan to ensure reliable guarantees of protection of the rights and freedoms of criminal offenders in criminal proceedings, to prevent the humiliation of their honor and dignity.

Chairman of the chamber of advocates of the Republic of Uzbekistan Ravshan Ahmedov said: "By the end of 2017, Uzbekistan will develop a draft law on the protection of victims, witnesses and other participants in criminal proceedings. The law provides for their physical and social protection to be 
guaranteed by the state". Based on the above, on january 14, 2019, the law of the Republic of Uzbekistan "On protection of victims, witnesses and other participants in criminal proceedings" No. O‘RQ-515. was adopted.

With the adoption of the above law, a number of existing problematic situations in the Criminal procedure code have been eliminated. At the same time, issues that have not yet been resolved in this area of criminal proceedings have survived to this day.

Ensuring the safety of witnesses is one of the most pressing issues for law enforcement agencies around the world, including in the Republic of Uzbekistan. If we pay attention to foreign experience, the following will appear.

In the United States, the Federal Witness Safety Program (WITSEC) at the disposal of the Department of justice has created a protection system with the most reliable and necessary ways to ensure the safety of threatened witnesses, and this program includes:

$>$ Establishment of funds for witnesses;

$>$ Signing a memorandum of understanding with a witness;

$>$ Development of memorandum procedures;

$>$ Responsibility for the disclosure of information about witnesses;

$>$ Assess the real threat to witnesses for inclusion in the security program;

$>$ Enforcement of the witness's obligations.[2]

Measures to ensure the safety of witnesses in Italy 70-ies of the 20th century. The Italian legislative decree of 2001 defines the following basic rules:
a) the protected person;
b) protective appearances.

Witnesses include persons assisting law enforcement agencies on a confidential basis, as well as former members of a criminal association serving a sentence in a penitentiary institution.

On August 20, 2004, the law of the Russian Federation "On state protection of victims, witnesses and participants in criminal proceedings"[3] was further improved and the Department for ensuring the security of state protected persons was established by the decree of the then President of the Russian Federation Dmitry Medvedev. In addition to witnesses, this department is responsible for ensuring the safety of life and property of employees of the bodies of fish control, protection of natural and cultural resources.

Summarizing the above, it is stipulated that the inclusion of western countries in the protection program in the United States, Italy, Germany should be protected on the basis of the circumstances of the case, not for every witness under threat, but for criminal cases against criminal organizations of special importance. In the Russian Federation, the nature of the threat to witnesses is determined by the inquiry officer, investigator, court, unlike in western countries. This can lead to an increase in the workload of the bodies responsible for the safety of witnesses and the misuse of public funds, even in criminal proceedings for the protection of witnesses, which do not pose a significant social risk.

In the legal literature, it is the organized criminal structures that are recognized as the main threat to the lives and property of witnesses and victims. In particular, the Uzbek scientist A.Sh.Umarkhanov emphasizes the importance of improving the current legislation of the Republic of Uzbekistan to increase the effectiveness of the protection of the rights and legitimate interests of witnesses 
in criminal proceedings on the following criteria.

$>$ Development of a legal mechanism to ensure the safety of participants in criminal proceedings;

$>$ Amendments to the existing criminal law governing the liability for unlawful influence on witnesses and victims, based on today's requirements;

$>$ Development of incentive procedural and legal norms aimed at protecting the participants of the process who conscientiously perform their service or civic duty.[4]

The code of Criminal procedure of the Republic of Uzbekistan contains provisions on the security of witnesses, and Article 270 is entitled "Ensuring the safety of participants in criminal proceedings". According to him, in the event of a threat to the victim, witness or other persons involved in the case, as well as their family members or close relatives to death, use of force, destruction of property, or other illegal actions, the inquiry officer, investigator, prosecutor or court shall to issue a written instruction to take the necessary measures to ensure the protection of life, health, honor, dignity and property of the said persons.

In particular, Article 238 of the Criminal code of the Republic of Uzbekistan also provides for liability of the victim and the witness for perjury. In our view, part 2 of this article has a special meaning in encouraging a witness and the victim or their close relatives to give false testimony through psychological or physical pressure. Because in forcing a false witness to testify, the subjective side manifests itself in the true form of guilt. In addition, during the inquiry and investigation, it must be established that the witness or victim is giving false testimony in his or her own personal interest or as a result of external influence on him or her. In particular, we believe that coercion to testify falsely is different from the crime of perjury.

In view of the above considerations, it is proposed to add Article 2303 to Chapter 16 of the Criminal code in the following wording.

\section{Article $230^{3}$. Coercion to give false testimony.}

Forcing a victim, witness or other participant in a criminal proceedings to give false testimony or perjury -

Is punishable by 1 to 3 years of correctional labor or 1 to 3 years of restriction of liberty or 1 to 3 years of imprisonment.

Those actions:

a) by a repeat or extremely dangerous recidivist;

b) committed by an organized group or in its interests, -

It is punishable by 3 to 5 years of restriction of liberty or 3 to 5 years of imprisonment.

In particular, Article 127, Part 4 of the Criminal procedure code of the Republic of Uzbekistan should be amended as follows:

When it is not possible to show the person for identification or for security reasons, this investigative action can be carried out using a photograph of him or a tinted window that allows him to see only from one side.

The use of one-sided, tinted windows to identify a person increases the security of witnesses and victims, as opposed to photographic identification. should be taken into account.

The above experience is used in the system of law enforcement rates of the Republic. However, the code of Criminal procedure of the Republic of Uzbekistan has not yet included a norm on this procedural action. 
In conclusion, the inclusion of the above proposals in the Criminal code and the code of Criminal procedure of the Republic of Uzbekistan will protect witnesses from the threat of organized crime, ensure their rights and freedoms, as well as property inviolability. Most importantly, it would create a basis for further growth of citizens' confidence in law enforcement agencies.

\section{REFERENCES}

1. Decree of the President of the Republic of Uzbekistan" on the strategy of further development of the Republic of Uzbekistan" Collection of legislation of the Republic of Uzbekistan. 2017. -№ 6. Article 70.

2. United Nations Office on Drugs and Crime. "New York. Good practices for the protection of witnesses in criminal prceedings involving organized crime".-United Nations.2008.p.8. www.unodc.org

3. Federal Law of the Russian Federation of August 20, 2004, No. 119-FZ, as amended on December 29, 2004, "On the State Protection of Victims, Witnesses and Other Participants in Criminal Proceedings" http: //www.zakon.ru.

4. Umarxonov A.Sh. "Problems of improving legal measures to ensure the safety of persons assisting in justice." PhD. autoabstract. T:. MIA of the Republic of Uzbekistan 2004. -P. 1011. 